\title{
Challenges to STS Education: Implications for Science Teacher Education
}

\author{
Nasser Mansour* \\ University of Exeter, United Kingdom and Tanta University, Egypt \\ This paper published in Bulletin of Science, Technology and Society (2007) Vol. 27, \\ No. 6 December, $482-497$.
}

\begin{abstract}
As future citizens, students must make decisions requiring an understanding of the interaction of science and technology and its interface with society. ScienceTechnology-Society (STS) education has been strongly identified with meeting this goal, but putting theory into practice has so far been difficult. This paper asks: "What are the challenges influencing science teachers to implement Science-TechnologySociety (STS) Education in the science classroom?" This was investigated using a mixed method research technique incorporating multiple sources of qualitative and quantitative data (questionnaire, interviews, field notes and classroom observations). Constraints affecting teachers' practices in teaching science through STS education were identified, and can be categorized into impersonal, interpersonal and personal constraints. Findings indicated interactions within and between external and internal constraints. Suggestions are made for implementing change in various aspects of Science Teacher Education.
\end{abstract}

Key words: Impersonal-interpersonal-personal constraints; Science-TechnologySociety (STS); Science Teacher Education; Egyptian Science Education.

\section{Introduction}

There is a growing body of research argues that teachers' beliefs should be studied within a framework that recognises the influence of culture (Kagan, 1992; Pajares, 1992). There is also an argument that teachers' beliefs and practices cannot be examined out of context, but are always situated in a physical setting, in which constraints and opportunities may arise from sources at various 'levels', such as the

\footnotetext{
* Mailing address 1: Faculty of Education, Tanta University, El-Giesh Street, Tanta, Gharbia, Egypt. Mailing address 2: School of Education and Lifelong Learning, University of Exeter, Heavitree Road, Exeter, EX1 2LU, UK.

E-mail: mansournasser@hotmail.com / telephone: 0044(0)7979438868
} 
individual classroom, the school, the principal, the community, or curriculum (Barnes, 1992; Hamiton and Richardson, 1995, Olson, 1988). It is argued that our understanding of the processes of science teaching and learning is better when we understand the constraints that affect the teaching and learning process. The role of contextual constraints or mediating factors on the teaching and learning process has been largely missing in studies done in Egypt (Gahin, 2001). Yet, knowledge about mediating factors within a given context might help explain why there is inconsistency between some teachers' beliefs and practices (Mansour, 2006).

Researchers in different fields define common external stresses which affect teachers' performance. These stresses include: work overload, time restraints, and problems with child behaviour, working conditions, relationships with colleagues, lack of resources, and the physical demands of teaching (Borg, Riding, \& Falzon, 1991; Borg, 1990; Blase, 1986). Kelly \& Berthelsen, 1995) identified similar sources of constraints for teaching practices such as time pressures, children's needs, nonteaching tasks, personal needs, parents' expectations, and interpersonal relationships. A qualitative study carried out by Blase (1986) with elementary, middle, and high school teachers, emphasised that time was one of the most important constraints and it cannot be understood independently of the other constraints because they were perceived as directly interfering with the instructional time of teachers. Examples are student discipline, student apathy, student absences, inappropriate scheduling, large classes and athletic events..

In the area of teaching/learning Science, Technology and Society (STS) issues, the study of Pedersen and Totten (2001), with 37 science teachers representing rural, urban and suburban areas identified some major reasons why science teachers seem to be reluctant to discuss or teach about STS issues. These reasons include: 1) Teachers believe that they lack the outside support from parents and their community to do so; 2) Teachers also believe that they lack the internal support of faculty and staff when attempting to introduce controversial issues into their science curriculum; 3) Cultural expectations of communities might influence the development of the curriculum; 4) Teachers are presenting information to students based on textbooks that teachers believe are deficient in the area of social issues. More than $65 \%$ of teachers reported that they use the textbook as the major guide for their curriculum; 5) Teachers believe 


\section{N. Mansour / Challenges to STS Education}

that neither in-service nor pre-service education provides adequate support for their understanding of social issues; 6) Teachers rely on easily accessible sources for their information on social issues.

In their study of implementing STS education through action research, Pedretti and Hodson (1995) found that working with teachers might not always be sufficient, in itself, to effect significant change on implementing STS curricula. They argue that the structure of the school system- in particular, its bureaucracy, administrative procedures and values- can combine to create and sustain an institutional climate that is not favourable to or supportive of change. They also suggested that there are many occasions when teachers are constrained from implementing a curriculum consistent with their personal beliefs about science and science education through lack of time, an over-crowded syllabus, inadequate facilities, pressure of external examinations, or class management problems arising from unsupportive administrative structures. Similarly, Cornbleth (2001) consider that a bureaucratic school climate with an administrative emphasis on 'law and order' is a primary constraint on meaningful teaching and learning. By 'law and order' he means following the school-wide rules (e.g. attendance, dress, homework, grading) and keeping classrooms, toilets, and hallways, clean and quiet. According to the 'law and order' emphasis, the underlying assumption seems to be that centralized order is prerequisite to teaching and learning. Zeichner, Tabachnick, and Densmore (1987) have also shown how technical controls such as scheduling, team-teaching, structured instructional materials, and external exams can shape teachers' beliefs and practice in ways that inhibit teaching for meaningful learning and critical thinking that incorporates diverse perspectives and students. It seems likely that law and order climates in schools are the product of a mix of personal, bureaucratic, and technical controls.

Abell \& Roth (1992) suggest that the interactions amongst the external and internal constraints magnify the negative effects on practice. Otto (1986) also noted that the interaction between these constraints leads to stress. Otto provided a model which described this process of 'stress' as a lack of fit between the external demands of the situation, the external resources and constraints, the internal demands of the individual and the internal resources and constraints perceived by the individual. 
Ertmer, Addison, Lane, Ross, and Woods (1999) examined the relationship between external and internal factors in relation to teachers' perceptions of instructional technology use and concluded that teachers' beliefs about classroom practice appeared to shape their goals for technology use as well as the weight they assigned to different barriers. They argued that the first-order external factors (equipment, time, and support) are easier to observe than the second-order internal factors (teachers' beliefs about teaching, computer use for instruction, and their willingness to change). Although the researchers do not make an explicit conclusion about the relationship between the internal and external factors to determine the weight of their effect on teachers' perceptions of technology use, the researchers stated that "second-order (internal) barriers may persist even when first-order (external) barriers are removed". Research Questions

The main research question is, "What are the challenges that influence science teachers to implement Science-Technology-Society (STS) Education on the science classroom?" To answer this question, the study poses three sub-questions;

- What are science teachers' views of the constraints that affect the implementation of Science-Technology-Society (STS) Education in the science classroom?

- How these constraints influence science teachers' performance to teach science through STS Education?

- What is the relationship among these constraints?

\section{Method}

It is clear that there is no single method that ensures that research data obtained are valid and reliable. Studying teachers' belief systems is a problematic field of research (Kagan, 1992) mainly because teachers' beliefs cannot be accessed directly (Pajares, 1992). Secondly, teacher's beliefs are usually held unconsciously (Kagan, 1992). Therefore, teachers may not possess the language to verbalize their beliefs. Thirdly, teachers can be unwilling to promote beliefs that are unpopular. Lastly, beliefs seem to be highly contextualised as they are associated with specific classrooms, events, materials, and students (Kagan, 1992). 
The data collection techniques used in this study have potential strengths and weaknesses. One way to emphasise the strengths and minimise the weaknesses is to use complementary multiple methods of data collection for triangulation (Denzin and Lincoln, 2000). Moreover, using multiple methods can eliminate some of the biases that can occur when only one method is used and would result in findings that are more representatives of participants' beliefs (Denzin \& Lincoln, 2000).

\section{Data collection}

In this study, two types of triangulation were adopted: methodological triangulation and researcher-participant triangulation. The first refers to the use of multiple data collection methods (questionnaire, interview, and observation) that avoid the reliance on one method to explore the participants' beliefs and practices. The second involved cross-checking the meaning of data obtained from the various methods with the participants. In other words I used each participant as a "running triangulation check" to ensure that I had correctly interpreted what they had said or what I had observed.

\section{Questionnaire}

The researcher designed a questionnaire to assess teachers' views about the constraints of teaching science through science, technology and society education. The questionnaire consists of 18 items, combining five-Likert-type (11) items, ranking (7) items, and an open-ended item. It was piloted with 126 science teachers, and the pilot study proved that it was appropriate for the main study. According to Bell (1993), the reliability of a research instrument is increased when tested on a pilot sample that shares a comparable profile with the main study sample. The sample of the pilot study was similar to the main study sample in many traditions. In the main study sample, the samples in the two pilot studies were preparatory science teachers, from the same culture. All the teachers in the pilot and in the main study had attained BSc degrees at universities in Egypt, and most had attended in-service training in UK universities. All the teachers in both the pilot study and the main study had taught science curricula for preparatory schools in Egypt. 
In this research, Cronbach's coefficient alpha was used to calculate the internal consistency coefficients of the items included in the questionnaire. Results of the reliability analysis showed that the items in the questionnaire had a satisfactory discriminating power and a high internal consistency. Reliability coefficient alpha obtained for the scale was 0.67 .

\section{Interviews}

I chose the interview as a method where the qualitative interview "...is a uniquely sensitive and powerful method for capturing the experiences and lived meanings of the subjects' everyday world. Interviews allow the subjects to convey to others their situation from their own perspective and in their own words" (Kvale, 1996,:70). Interviewing is considered one of the most potent ways, in qualitative research, of understanding others, because it allows the researcher to access to individual's beliefs, wishes and intentions in their own words rather than in the words of the researcher (Taylor \& Bogdan, 1998).

I piloted the questions of the semi-structured interview with two preparatory science teachers in Egypt. Having finished the pilot study, I considered the interviewees' comments and added more questions to the protocol of the interviews for the main study, the pilot study having indicated to me the time required to conduct the interview, and helped me to identify inappropriate or ambiguities wording and the validity of the interview questions.

The interviews were audio-taped and transcribed immediately after the interview. The transcripts were returned to each of the teachers for their scrutiny, confirmation or criticism before the beginning of the next interview. After each interview I also made an initial analysis of the interview and wrote notes on a covering sheet to act as a framework for subsequent questions. Thus the process was concerned with "the unique, the idiosyncratic, and the wholly individual viewpoint" (Guba and Lincoln, 1989: 155-156). All the interviews lasted for 30 to 45 minutes. Each interviewee had 4 or 5 observations and interviews. 


\section{Research sample}

The study used two samples: one for the questionnaire and the other one for the qualitative study. The questionnaire sample was selected randomly, covering a variety of teacher qualifications, and specializations, and a range of teaching experience, age, and school locations. A total of 162 Egyptian preparatory science teachers out of 200 teachers (schools with students' age 11-13) responded to the questionnaire.

After analyzing the questionnaires, the maximum variation strategy was used to sample ten teachers with diverse beliefs about teaching science through STS issues (Patton, 2002). The sampling was designed to include a broad variety of informant experience based on gender, unique teaching situations, a variety of teaching expertise (novices vs. experienced teachers), and varied experiences of teaching at different preparatory grade levels. Thus, the ten participants chosen for this study were chosen from different preparatory schools in Gharbia Governorate in Egypt, and represented all grade levels, as well as a diversity of age, gender, and teaching experience. More specifically, the participants consisted of 5 males and 5 females, with teaching experience that varied from ten to twenty-three years of teaching and ages ranging from the mid-30s to early 50s. These teachers have been represented in this study by letters (A, Z, F, M, N, S, W, V, B, and H).

\section{Results}

\section{Questionnaire results}

Teachers' responses as shown in Table 1 indicate the 'pressure of examinations' was the most frequently noted constraint. A high percentage of the teachers $(92.6 \%)$ saw 'preparing their student for the final exams which are content-oriented' as the biggest obstacle to teaching science using STS content. One of the factors that make this the most serious problem from the teachers' perspectives was the pressure exerted by parents, students, headmasters, decision makers and inspectors on teachers. This is because in Egypt the teachers' performance is judged by the success of their students in the final exams. In other words, exam results are used as indicators of pupils' learning and evidence of effective teaching and the annual report of teachers' 
performance is dependent on how many students passed the final exam. What makes matters worse is the mismatch found between an exam orientation and the explicit aims of science education e.g. developing scientific literacy and developing required skills, including analytical skill, critical thinking, scientific skills and problem (UNESCO, 2000). Moreover, what exams focused on is the memorising of the content in the science textbooks.

Table 1: teachers' beliefs regarding outside influences/ constraints

\begin{tabular}{|c|c|c|c|c|c|c|c|c|c|c|c|c|c|}
\hline \multirow[t]{2}{*}{ Items } & \multicolumn{2}{|c|}{ SD } & \multicolumn{2}{|l|}{$\mathrm{D}$} & \multicolumn{2}{|l|}{$\mathrm{U}$} & \multicolumn{2}{|l|}{ A } & \multicolumn{2}{|c|}{ SA } & \multirow[t]{2}{*}{ Mean } & \multirow[t]{2}{*}{ St. } & \multirow[t]{2}{*}{ order } \\
\hline & $\mathrm{F}$ & $\%$ & $\mathrm{~F}$ & $\%$ & $\mathrm{~F}$ & $\%$ & $\mathrm{~F}$ & $\%$ & $\mathrm{~F}$ & $\%$ & & & \\
\hline $\begin{array}{l}\text { The pressure of preparing students for } \\
\text { the final examination, which emphasise } \\
\text { the traditional science content. }\end{array}$ & 0 & 0 & 6 & 3.7 & 6 & 3.7 & 59 & 36.4 & 91 & 56.2 & 4.45 & 0.73 & 1 \\
\hline Large classes & 2 & 1.2 & 13 & 8 & 7 & 4.3 & 31 & 19.1 & $\begin{array}{l}10 \\
9\end{array}$ & 67.3 & 4.43 & 0.98 & 2 \\
\hline $\begin{array}{l}\text { The pressure of trying to cover the } \\
\text { prescribed syllabus. }\end{array}$ & 0 & 0 & 17 & 10.5 & 5 & 3.1 & 54 & 33.3 & 86 & 53.1 & 4.29 & 0.96 & 2 \\
\hline $\begin{array}{l}\text { Lack of and difficulty in getting enough } \\
\text { relevant resources to teach STS issues. }\end{array}$ & 2 & 1.2 & 18 & 11.1 & 3 & 1.9 & 65 & 40.1 & 74 & 45.7 & 4.2 & 1.00 & 3 \\
\hline Insufficient pre-service preparation. & 0 & 0 & 15 & 9.3 & 13 & 8 & 49 & 30.2 & 85 & 52.5 & 4.26 & 0.96 & 4 \\
\hline Insufficient in-service training. & 1 & .06 & 29 & 17.9 & 9 & 5.6 & 39 & 24.1 & 84 & 51.9 & 4.10 & 1.16 & 5 \\
\hline $\begin{array}{l}\text { Lack of interest of students in learning } \\
\text { STS. }\end{array}$ & 9 & 5.6 & 28 & 17.3 & 6 & 3.7 & 69 & 42.6 & 50 & 30.9 & 3.75 & 1.22 & 6 \\
\hline $\begin{array}{l}\text { I do not feel that I would be supported } \\
\text { by the parents of my students in teaching } \\
\text { STS issues. }\end{array}$ & 11 & 6.8 & 42 & 25.9 & 26 & 16 & 55 & 34 & 28 & 17.3 & 3.2 & 1.2 & 7 \\
\hline $\begin{array}{l}\text { My co-workers do not provide me with } \\
\text { support in regard to teaching about STS } \\
\text { issues. }\end{array}$ & 26 & 16 & 53 & 32.7 & 12 & 7.4 & 37 & 22.8 & 34 & 21 & 3.0 & 1.4 & 8 \\
\hline $\begin{array}{l}\text { Lack of confidence in teaching STS } \\
\text { issues. }\end{array}$ & 14 & 8.6 & 35 & 21.6 & 45 & 27.8 & 39 & 24.1 & 29 & 17.9 & 3.20 & 1.2 & 9 \\
\hline $\begin{array}{l}\text { My principal does not support me when } \\
\text { I am trying new ideas in my classroom } \\
\text { such as STS issues. }\end{array}$ & 15 & 9.3 & 42 & 29.4 & 39 & 24.1 & 33 & 20.4 & 33 & 20.4 & 3.1 & 1.27 & 10 \\
\hline
\end{tabular}

'Covering the science syllabuses' and 'large class size' were the second most serious constraint as judged by vast majority of teachers $(86.4 \%)$. Covering the science syllabus was a problem facing the teachers in implementing STS in their classes because the teachers not only have to explain all the lessons, but also have to take on many non-teaching roles (e.g. attendance, dress, and keeping classrooms hallways, clean and quiet). Moreover, the teachers have to teach with large numbers of students that does not allow for the use of individual teaching techniques or even cooperative learning, or deducing scientific knowledge by discovery. All these are prerequisites for science education according to the STS. The responses as shown in Table 1 indicate that the respondents have a tendency to focus on constraints that they have no 
control over (e.g. insufficient pre-service preparation $82.7 \%$, lack of STS resources $85.8 \%$, lack of student interest $73.5 \%$ ) more than on factors coming from within themselves (e.g. lack of confidence to teach using STS $42 \%$ ).

To give the teachers a chance to share their experiences, an open-ended question asked them to specify any other problems that they might face in teaching STS issues. Responses to this question come under five main categorises:

- Time constraints $95 \%$;

- Teachers' economic constraints $78 \%$;

- Work overload 75\%;

- The orientation of the science curricula $68 \%$;

- Constraints linked with parental expectations $65 \%$.

To double check the teachers' responses, the teachers were also asked to rank 7 difficulties that they might face when teaching using STS with ' 1 ' being the most difficult problem and ' 7 ' the least difficult.

Table 2: Priority frequencies and means of seven difficulties in teaching STS issues

\begin{tabular}{|l|l|l|l|l|l|l|l|l|l|}
\hline & \multicolumn{3}{|l|}{ Priority frequencies } & $\begin{array}{l}\text { Average } \\
\text { priority } \\
\text { index }\end{array}$ & order \\
\cline { 2 - 12 } & 7 & 6 & 5 & 4 & 3 & 2 & 1 \\
\hline Evaluation and examination system & 308 & 252 & 130 & 72 & 69 & 8 & 5 & 5.2 & 1 \\
\hline Excessive number of students in class & 329 & 102 & 125 & 100 & 27 & 34 & 22 & 4.56 & 2 \\
\hline $\begin{array}{l}\text { Covering the subject matter in the } \\
\text { curriculum. }\end{array}$ & 91 & 156 & 200 & 68 & 102 & 42 & 11 & 4.13 & 3 \\
\hline Lack of available curriculum materials & 238 & 90 & 60 & 68 & 36 & 44 & 49 & 3.64 & 4 \\
\hline $\begin{array}{l}\text { Absence of STS courses during } \\
\text { academic preparation on the university. }\end{array}$ & 63 & 126 & 85 & 126 & 99 & 62 & 16 & 3.62 & 5 \\
\hline Absence of suitable in-service training. & 56 & 120 & 130 & 56 & 108 & 52 & 31 & 3.41 & 6 \\
\hline $\begin{array}{l}\text { Unavailability of teaching aid } \\
\text { resources (e.g. computers and high } \\
\text { technology). }\end{array}$ & 49 & 126 & 75 & 140 & 45 & 82 & 28 & 3.36 & 7 \\
\hline
\end{tabular}

The results as shown in Table 2 show there was agreement between teachers' responses on 'the beliefs about the constraints of implementing STS (BACISTS) scale' as shown in Table 1 and their responses to this item. For example in both Table 1 and Table 2, the 'examination constraint' came first, class size came second and curriculum constraints', 'lack of materials', 'pre-service preparation' and 'in-service training' followed these. 


\section{N. Mansour / Challenges to STS Education}

\section{Qualitative results}

The quantitative analysis above indicates what might make a difference in a particular context. However it does not indicate which contextual factors are relevant or how the constraints identified interacted to shape teaching practices and pupils' learning opportunities. To enhance our understanding and to be useful in an interpretive sense (Cornbleth, 1991), qualitative analysis is needed to illustrate how constraints operate in particular times and places

The qualitative analysis indicates that constraints can be categorised into two sorts: external constraints and internal constraints. External constraints refer to the factors outside the teachers' control, for example examination systems, lack of time, work overload, a large number of pupils in the classrooms, lack of STS resources or materials, the content, etc. Internal constraints refer to factors related to the teachers themselves, for example their knowledge base, background and experience in STS issues, teachers' professional abilities etc. Both types of constraints were shown to be related and they interacted together to affect the way teachers put their beliefs into practice. The interactions among impersonal, personal, and interpersonal constraints and their influences on teachers' practices are summarized in Figure 1.

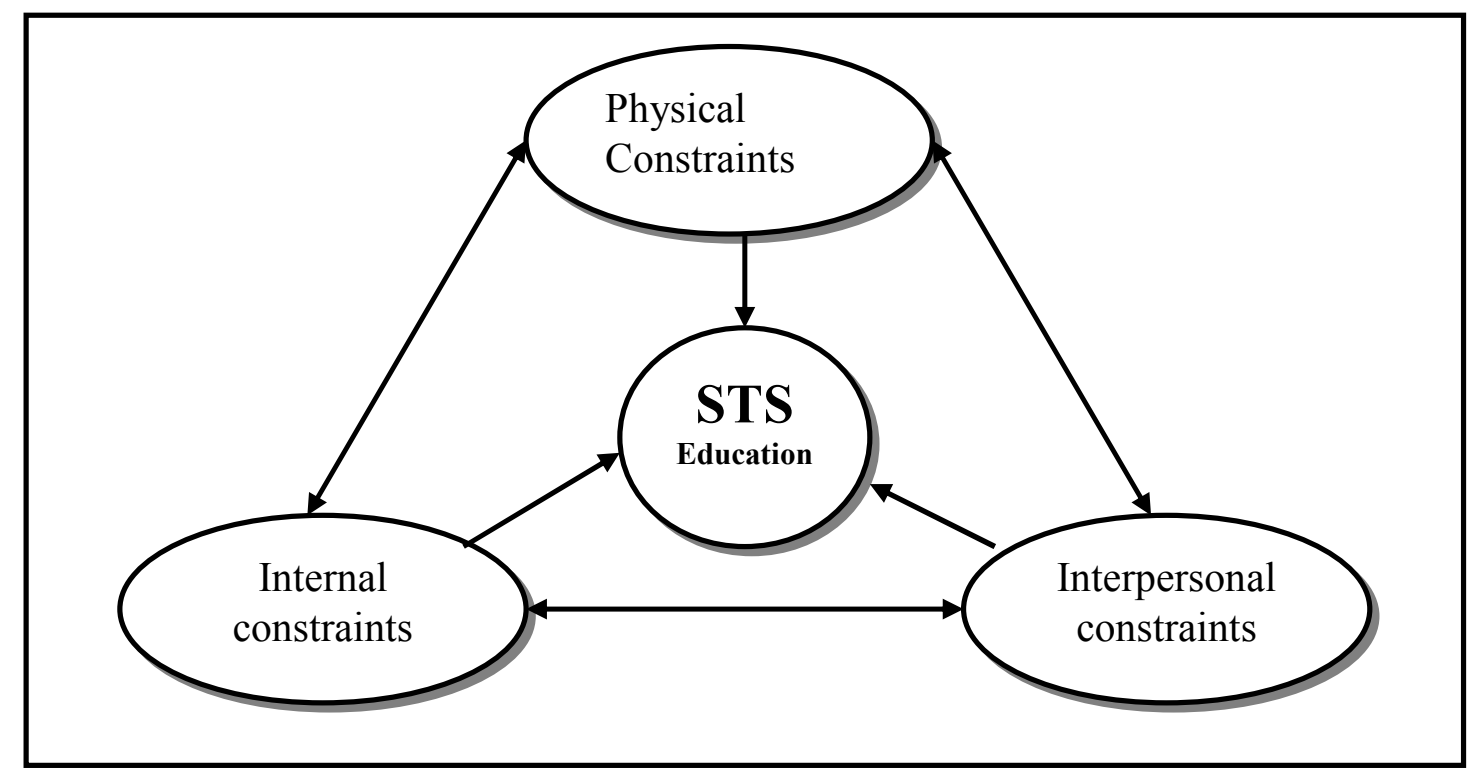


Figure 1: The Constraints on STS Education

\section{External constraints}

Analysis of the semi-structured interview data) revealed that external constraints came into two categories: physical constraints and interpersonal constraints.

\section{External physical constraints}

External physical constraints included Examination system, lack of Time, overload work, high density in the classrooms, STS resources or materials, the content, private lessons. The following is a detailed description of how these constraints affected the ways in which teachers put their beliefs into practice.

\section{1- Examination system}

From the informants' point of views, the inclusion of STS education in the Egyptian school is deterred by the examination system. The teachers tackled social and technological issues and their applications, but without concentration because such issues are not included in examination. Teacher W said,

"I myself don't give these issues much space because I am, as a teacher, controlled by an examination system, which is imposed on me" (T/W)

The outcome of exams was the main interest of Students, parents, school administrations. One teacher commented,

"The current exam system is the horse and the remaining components of the educational system are the carriage. In other words, the various elements of the educational process including the teacher, the student, the curriculum, administration are directed towards exams" (T/W).

Another comment said,

"The science teacher from the viewpoint of the administration, the inspectors and parents is similar to the football coach in that he is required to prepare students and train them using different evaluation techniques and varying questions that focus on memorization, so they can get through exams" (T/V).

The teachers seem to be highlighting two ways in which the exams system affects the implementation of STS beliefs. One teacher's comment said, 
"The exam models that the ministry formulates focus only on the achievement of the content. They do not assess students' attitudes or behaviours, their scientific literacy, or their understanding of the interactive relationship between science, technology and society. The problem is that these models are determiners of the way teaching and learning should be done" (T/A).

Teacher F commented,

"Exams at the end of educational stages are called competition exams. Students are in a continuous competition with one another. As a teacher, I have to prepare the student to get through this race. This is the expectation of parents and administration" $(\mathrm{T} / \mathrm{F})$.

\section{2- Lack of Time}

The short class time was seen as an obstacle to the implementation of STS, especially with high classroom density. All of the participants felt that they had a limited amount of time in which to help the students achieve the STS goals. Teacher H gave these comments,

"The STS approach is of great value for the teacher and the learner, but time makes it difficult for the teacher to use it. As I know it needs time beyond the time allocated to traditional classes. A class lasts for 45 minutes. This time is allocated as follows:

- Ten minutes for greeting the students, checking attendance and controlling the students;

- Ten minutes for reviewing the previous lesson, answering students' questions about it, and presenting the new lesson.

- Twenty minutes for explaining the new lesson and do as many activities as possible;

- Five minutes for dictating the elements of the lesson and giving the homework." (T/H)

Teacher $\mathrm{Z}$ feels pressurized due to the lake of time. She said;

"As a teacher there is no time to do what I like to do. Sometimes I like to use role play to teach STS issues like pollution or using chemical materials and the effect of these problems on our society and what the students can do if they were decision makers. But because I have fixed content and limited time I try to manage these problems by using discussion or short inquiry" (T/Z)

Preparation time was the second area in which participants discussed time constraints. In this study, preparation time includes preparing to teach class, time for grading, and for working with individual students. Time is a significant factor in the STS instruction. Teachers, in the preparatory and secondary stages, have a time plan, which they have to adhere to. The time allocated to the class is limited. Science 
teachers have to plan for their lessons taking into account the limited time of the class. Time is allocated to different topics in the content according to the nature and the weight of the topics. As a result, teachers plan for lessons with different times in their minds for daily and weekly teaching. Their visualizations of the time needed in the STS lesson in comparison with traditional lessons affect their planning and teaching of the STS. The constraint of limited preparation time tended to influence the participants' practices for their STS classes and teaching methods. One comment said,

"An STS class needs much more time for managing and organizing the class. Strategies like problem solving, brainstorming or cooperative learning entail group work, which, in turn, entails reorganizing the students. So, I recommend that STS lessons be grouped in special units and allocated enough time" (T/B).

Another comment said,

"Although I'm convinced that the importance of science lies in relating it to real life outside school, I cannot do this or more expressively I'm not allowed to do this. I'm required to teach the curriculum in a given time span" (T/A).

\section{3- Overload work}

The Egyptian science teachers are overburdened by having to perform many roles. They have to list and prepare the necessary lab instruments and tools every class. Then, they have to do the experiments and rearrange the instruments. They are also required to use audio-visual aids. This makes them resort to the simplest teaching methods like verbal explanation. Sometimes, they use demonstrations getting students to deduce knowledge, but students are not provided with the opportunities to train on the manual skills.

In addition to carrying out the daily routine tasks like controlling the students in the morning queue and checking attendance, he teaches a large number of classes, an average of 24 classes weekly. Thus, I notice through the field study whether in experimental or public schools, that science teachers teach a large number of classes. This leads to the neglect of out-of-class learning activities (e.g., field trips, carrying out projects, preparing science clubs, etc), which are necessary for the STS education (Brusic, 1992; Bonnstetter \& Pedersen, 1993). The teacher keeps moving from a classroom to another throughout the school day. He has no time to present educational 
services relating to the STS to his students. He finds himself obliged to just teach his daily classes and yet feel physically, mentally and psychologically tired due to the big number of classes he teaches a day. In such circumstances, the teacher cannot be expected to discuss the STS issues.

One teacher $\mathrm{H}$ commented

"How can I discuss issues that relate to the society whereas I have to teach such a big number of classes and take part in administrative affairs".

Teacher $\mathrm{N}$ gave another comment;

"We are loaded with extra work. Much of that work doesn't have anything to do with the classroom. I try to do my best but sometimes you have no choice to teach directly by lecture method or to control the students so you can finish the lesson on time"

Another comment about workload of the teachers said,

"The teacher has many non-teaching roles to perform. He has to check attendance, which is time consuming because of the big number of students in the classroom. The teacher should make sure that the classroom is clean or he will face trouble with the school administration" $(\mathrm{T} / \mathrm{S})$.

\section{4- High density in the classrooms}

Like other developing countries, education in Egypt is quantitative expansion at the expense of qualitative expansion. High classroom density as noticed by the researcher makes it difficult for the teacher to guide and help individual students as required in inquisitive, problem solving and cooperative learning techniques. In brief, such dense classrooms make the adoption of the STS education rather difficult. One comment said,

"The problem with this STS approach is that it suits only classes with small number of students. This isn't a problem in my school where classrooms don't exceed 45 students in the primary stage, 30 students in the preparatory stage, and less than 25 in the secondary stage. Classes in other schools can mount to 70 students. These many students sit in narrow classrooms. How they can discuss STS issue in this environment" (T/A). 
Teacher V cited:

"How can I do a lesson about STS with so many students (56 students) and do it properly? How can I listen or discuss the students' different views on STS issues? I am sure that my students are different but the problem I do not have the time for them or to meet their needs" (T/V).

In the same respect, teacher $\mathrm{W}$ gave a reason why he believes on the lecture as a good strategy for teaching science through STS. He said;

"I have around (40-50) student on my classes. If I like to use at least discussion to teach one of STS issues and to encourage students to give their opinions freely and give just chance to ten students and give each one two minutes, that will be ideal and impossible. What we need is 20-25 students on the class to teach STS properly"

\section{5- STS resources or materials}

Teachers mentioned that there are no enough materials to implement STS in the Egyptian school.

One teacher said

"The library lacks up-to-date books that one can use to know about modern controversial issues" (T/F).

Teacher $\mathrm{V}$ also highlighted the lake of teaching materials as a reason of the mismatch between what she likes to do and what she actually practiced. She cited:

"I would like to use the co-operative learning strategy all the time to teach STS issues. Also, I like each group to have its own materials. I am sure the lesson will be more effective for the students when using co-operative learning. Each student would have the chance to discuss and argue within the co-operative group. The problem or the barrier is that the school has no resources" $(\mathrm{T} / \mathrm{V})$.

Another comments said,

"Absence of problems in the textbook will make students focus on the theoretical content and they will keep unaware of their social problems" (T/Z)

\section{6- The content}


The majority of the teachers see that the current science curricula focus on the cognitive aspect of knowledge and present the problems and issues of the STS briefly and after the presentation of lesson's scientific content. From her experience in teaching experience in the preparatory stage, teacher $\mathrm{Z}$ said,

"The curriculum in the preparatory stage focuses on cognition. It doesn't include but very few social problems. There are few problems in the first grade like pollution and one problem in the third grade, sound pollution. There aren't any problems in the second grade. That is, the current curriculum isn't good in terms of the social problems it covers. Yet, an interested and experienced teacher can relate some points in the curriculum to real life" (T/Z).

Teacher A commented,

"In the present time, it's difficult to relate science to students' life because the curriculum itself and its aims are not conducive to such relation. Reformulating the curriculum is, therefore, a must for this relation to be achieved" (T/A).

The participants view that science curricula in Egypt is a body of knowledge to be taught in a given time span and that limits the teacher's abilities. Teacher B gave comment regarding that. He said,

"The curriculum melds the teacher. The teacher finds himself confined to the curriculum to prepare the students to the final exam, which is put by another teacher. For this reason, the teacher is obliged to adhere to the curriculum even if it contains incorrect information and unrelated topics" (T/B/).

\section{7- Private lessons}

The majority of the Teachers mentioned to private lessons as a common reason for students' less motivation to be involved on STS discussion. The learners attend private lessons outside school, which can have a negative effect on the discussion of the STS issues. Teacher V said,

"Private lessons may help the learner with achievement and cause another problem. They kill the motivation for discussing the academic content in a social context". (T/V)

Another teacher gave comment that: 
"Learners come to school not to learn but to meet the condition of attending to school. This, in turn, makes the teacher lose motivation to get them discuss science in the STS context. Discussion is based on two sides: the teacher and the students. Loss of one side means loss of communication." (T/Z)

\section{External Interpersonal constraints}

External interpersonal constraints refer to the effect of the people with whom teachers deal during the educational process, like, the school administration and science inspectors, educational decision makers' aims, the family, the learners. Following is a detailed description of how these constraints affected teachers to put their beliefs into practice.

\section{The school administration and science inspectors}

Teachers mentioned that the school administration is to blame for the difficult implementation of the STS in the Egyptian school and for the negligence of activities related with STS education. It focuses on achievement rather than the social or technological aspects of the academic content.

One teacher's comment said,

"The school administration does not provide the finance that is necessary for carrying out scientific projects or trips, which is a main aspect of connecting science to students' social life. The administration considers such activities a waste of money and time. It also sees that such activities do not help students with achievement and getting through the final exams, which is the only concern for the administration" (T/F).

Also, teacher F added;

"School administration can frustrate the teacher and reduce his motivation to teach. For example, the teacher may get frustrated if the school administration refuses his proposal of making a scientific field trip to a given factory" (T/F).

Teacher V gave comment on the current role of the administration. She said, 
"The administration is mainly concerned with the teacher's preparation notebook. And it is only a formal concern. Thus, it cares about such trivial elements like the date of the class, the elements of the lesson plan, the title of the lesson, etc. The concern is not placed on the content of the lesson or its importance for the students. All teachers are treated this way. This discourages teachers who are interested in STS education. As a result, No teacher risks applying modern teaching methods like those of the STS" (T/V).

Added to this, the administration gives higher bodies formal reports that conceal facts and problems. That is, it depicts a picture that differs completely from reality. This way, aspects of weakness remain unchanged and so do the teacher's and the learner's level. As teachers said, the school administration should have a role in practice STS instruction since it makes possible the building of good citizens. Unfortunately, what happens is the opposite. Administration follows teachers only to hunt mistakes. It follows to see how far the teacher adheres to the plan set by the ministry. It also follows teachers' attendance and adherence to the specified times of the school day. Teacher $\mathrm{V}$ gave comment on the current role of the administration.

Teacher $\mathrm{M}$ stated in her interview,

"The administration and inspectors are mainly concerned with the formality of lesson planning. They are more interested in such points as the inclusion of behavioural aims in the lesson plan than in actual teaching inside the classroom" (T/M).

\section{Educational decision makers' aims}

The majority of the teachers claimed that they face another obstacle, which influenced their beliefs to put into practice. This obstacle was the aims and the expectations set by the Educational decision makers who are represented by Ministry of Education (MoE). The teacher A said,

"I'm obliged to follow a specified teaching plan and given topics. This plan is specified on the part of the ministry of education. Any drift away from this plan is a kind of violating the law. Any violation to this plan subjects the teacher to retribution" (T/A).

The teacher $\mathrm{H}$ also said,

"There are aims set by the ministry of education. One of these aims is the students' employment of the scientific content in real life. But 
such aims are formal, i.e., they are the declared aims but the hidden ones on which the ministry advocates focus on knowledge with all its levels. This can be noticed easily by examining models of exams and exercises presented to the students in all the educational stages" $(\mathrm{T} / \mathrm{H})$.

\section{The family}

Teachers saw that the family was one of the obstacles to the implementation of the STS education in the Egyptian school. Teachers also expressed that parents only had a general idea of what education is about and how it should be. For example, Teacher V cited:

"The family has no great role in improving the educational process. And when it interferes, it interferes negatively. The family is not concerned with science being interesting and relevant to real life. They are more concerned with the child's achievement of high marks, so he can join one of the top faculties like the faculty of medicine and the faculty of pharmacy." (T/V)

From teachers' views, most Egyptian families are unaware of scientific literacy and their role in developing their children's scientific literacy.

Teacher S said,

"The family does not encourage the child to follow scientific programmes on the TV or even buy scientific journals. This is thought of as a waste of time. The family sees that the student has to focus on studying the specified curriculum. Besides, it does not encourage the student to apply what they study in real life or even in additional school activities like science clubs" (T/S).

Teacher Z said:

"Most parents have the idea that their children should be able to pass the final exams. They conclude that our work is not good enough unless their students get high marks (T/Z).

\section{The learners}

The learners themselves, as confirmed by the teachers, also deter the implementation of the STS. The majority of the teachers thought that students acted as a barrier for teachers to teach according to their beliefs. Theses barriers ranged from students' 
backgrounds about STS issues, different abilities, and lack of co-operation, learning habits, interests, attitudes, and motivations.

Teacher Z said;

"Most learners do not follow the current events or the news. Thus, they are unaware of local or international problems which sometimes related to the content".

Teacher V said;

"Science is presented in a way that is boring and irrelevant to life outside school. That makes the students have negative attitude towards learning science. I try to give them examples about how science is applied on our life but that is not enough because the students always oriented and motivated with what comes on the textbooks."

Teachers A, N, B, F, S and H agreed that students' learning habits were one of the powerful factors that act as constraints of implementing STS on the science classes.

Teacher H explained that said;

"I teach science for a certain class 4 sessions a week and they attend other sessions for different subjects and most of the their teachers emphasise on the content and teach by direct method 'lecture'. The atmosphere of learning and teaching is oriented by the content and exams. By that process the students form habits and attitude toward learning. To change that, we need co-operation among all the teachers on different subjects."

Teacher (S) gave another example of the teaching/learning habits he said;

"The teacher finds himself obliged to teach the lesson in detail because if he leaves a part unexplained, the students cannot learn it, i.e., the students are completely dependent on the teacher. Moreover, the way students are evaluated encourages rote learning" $(\mathrm{T} / \mathrm{S})$.

Also, all of teachers $\mathrm{M}, \mathrm{B}, \mathrm{F}, \mathrm{V}, \mathrm{Z}$ and $\mathrm{A}$, mentioned to the students' expectations.

Student generally aimed to receive knowledge to pass exams.

Teacher (B) said;

"The students do not pay attention to any subject unless it comes directly on the textbook or on exams. They always think how they can pass the exam by simplest way. I am thinking about how can I make science related to their life. I prefer this, but most of the students would like to memorise what come on the textbook." 


\section{Internal constraints}

Examples of internal constraints include the teacher's background and experience about STS, the teachers' professional abilities and personal religious beliefs. These are discussed in some detail below;

\section{1- Teachers' background and experience about STS}

The teachers' knowledge of the content of the STS and its issues was another significant factor that affects the quality of the STS teaching. Teacher B highlighted from his experience that,

"I teach science in its connection with technological and social aspects, what's known as the STS, but this is a personal effort. Yet, my teaching according to this approach can be impromptu and I need to know the fundamentals of this new teaching" (T/B)

Another teacher also said,

"When we were college students, we heard nothing about the STS issues or the connection between science, technology and society. What we studied was an academic content and we used to keep it by heart only for exams" (T/S).

One teacher's comment said,

“The teacher's confidence weakens if s/he doesn't have sufficient knowledge. Sometimes I feel that my knowledge is close to my students' knowledge about an STS issue and that makes me so worried to discuss this kind of issues" (T/Z).

Teacher B concurred with what teacher $\mathrm{Z}$ said

"The teacher is required to be informed of all these aspects in order to be able to teach the STS issues. An important issue which students often ask about is colonisation. I've never heard of this issue but in mass media. And I cannot teach such an issue, as my specialization is physics and chemistry. If I were obliged to teach it, I'll be limited to what is mentioned about it in the textbook. My university preparation didn't extend to such issues. There are no inservice programmes to train teachers on such issues" (T/B).

All the teachers put the responsibilities of teaching and learning with STS on teacher education. For example, Teacher S said; 
"University teacher preparation programmes should include all the innovations concerning the STS issues" (T/S).

Anotherer comment said,

"Teachers should be offered in-service training courses. In these courses teachers can be taught to use the Internet in addition to the innovations in the field" (T/V).

\section{2- The teachers' professional abilities}

Many teachers were not prepared to teach the STS issues. Teacher Z said;

"I did not incorporate inquiry into my teaching till I did research about using inquiry as teaching method to develop students' creativity. The university' programme gave me theoretically a bunch of constructivist ideas. After I graduated, I tried to plan these in my lesson, but I could not. I believe that I was a lack of teaching experience. " (T/Z).

Teacher specialisation was another factor that limited teachers' abilities to science teach using STS. One comment said,

"I cannot teach all the issues of the STS. I only can teach the issues that are mostly biological, as biology is my major. For instance, I cannot teach an issue like "Health and man as my study in the university was restricted to biology and did not extend to other disciplines like chemistry and physics."(T/M).

Teacher $\mathrm{H}$ has a remarkable view about that,

"In my opinion, the teaching of the STS issues requires a scientifically literate teacher (One cannot give what s/he lacks) who is able to penetrate different disciplines and integrate them in one whole, the issue discussed. This should be considered in student teacher preparation and in-service programmes" $(\mathrm{T} / \mathrm{H})$.

Teacher W raised criticism against teacher education. He said, "I joined the faculty of education to be a teacher of Physics. So I cannot teach subject matters I have never been prepared or trained on. In my university study, I studied very little about biology, botany, zoology and geology. I studied nothing about the space science. And now I'm required to teach all these subject matters. I do my best relying on the textbook."(T/W).

\section{3- Teachers' personal religious beliefs}

Sometimes teachers' misunderstanding of the relationship between an STS issue and religion acts as a barrier to teaching this issue. Also, as teachers did not have 
sufficient knowledge about the relationship between science and religion, they decided not to teach these controversial issues. For example, Teacher S said:

There are a lot of STS issues that I can consider against Islam, like cloning. We shouldn't teach these issues in science curricula. (T/S)

Another teacher said:

To be on the safe side when teaching STS issues, I do teach using lectures without any discussion with students. So, they can get what I want to tell them correctly. (T/W)

Another teacher (A) said:

I try to be very careful when I teach some applications of science. I always look at the religious side of that application. I mean I look at the relationship between technology and science from religious aspects. For example, when I teach genetic engineering, I try to explain to my students about some awful some applications of genetic engineering which affect our nature and affect us negatively which is absolutely against our religious beliefs. (T/A)

Another commented:

If I don't feel confident enough with my religious knowledge about an STS issue which might relate to religion, e.g. organ donation, I will ask the student to memorize the textbook as it is. I don't want to upset religion or put myself in trouble. $(\mathrm{T} / \mathrm{B})$

Table (3) summarises the constraints identified by the teachers.

Table 3: External and internal constraints as identified by the teachers

\begin{tabular}{|l|l|}
\hline External constraints & Internal constraints \\
\hline (1) External physical constraints & Teachers' background and experiences (10) \\
Examination system(10) & The teachers' professional abilities (8) \\
Lack of time (10) & \\
Overload work (7) & \\
High density of the students (10) & \\
STS recourses or materials (10) & \\
The content (8) & \\
Private lessons (6) & \\
(2) External interpersonal constraints & \\
The school administration and inspectors (10) & \\
Educational decision makers' aims (10) & \\
The family (7) & \\
The Learner and learning motivation (5) & \\
\hline
\end{tabular}


The results reported from the qualitative data analysis are consistent with those obtained from the analysis of the questionnaire.

\section{Discussion}

The findings from the questionnaire, and interviews revealed a number of factors that routinely limited teachers' practices. These limitations were largely noticeable in their teaching, and were emphasised by teachers during the retrospective discussions of their observed lessons. Teachers considered constraints to act as boundaries that controlled their practices and delimited their intentions and attempts to enact their beliefs in practices (Gahin, 2001; Ajzen, 1988, 2002; Simonneaux, \& Albe, 2002). As a result most of the teachers in this study stated that they had to use more transmission methods than they actually wanted.

A number of models that consider the relationships between beliefs and practices have been put forward to explain how the constraints act as barriers to teachers putting their beliefs into practices. These models include Clack and Peterson's model of teacher thought and action (1986); Ernest's model of relationships between beliefs and their practice (1988); Bennett, Wood, and Rogers' conceptual model of teacher thinking and classroom practice (1997) and Maxion's (1996) model of teachers' belief systems. The findings of the present study concur with Maxion's (1996) model which suggests there are external and internal factors that directly affect teachers' practice. However, this study's findings do not agree with Maxion's model (1996) which claims that external and internal factors affect teachers' practice indirectly by affecting their beliefs first. The qualitative findings of this study showed that external and internal factors may directly affect teachers' practices or may indirectly affect them through affecting their beliefs first. For example, on one hand, the findings showed that their teacher training programme influenced their beliefs which in turn influence their practices On the other hand, class size and lack of time act as constraints and push teachers towards certain styles of teaching that they might not be happy with. In this example, class size or time constraints affect teachers' practices directly and impact or (re-) shaped-slowly their beliefs. The study's findings do concur with Maxion's (1996) argument that when these external and internal factors interfere with teachers' beliefs, classroom practice and beliefs are disjointed. However, the findings of Maxion's study raise questions about traditional ways of 


\section{N. Mansour / Challenges to STS Education}

viewing beliefs and teaching effects that practices always be affected directly by beliefs. The classroom actions are always viewed in terms of a direct model, where teachers' practices are directly influenced by their beliefs and in turn, teachers' actions are seen as having direct effects on students. The findings of this study appear to be more consistent with Blatchford et al.'s (2002) argument about the importance of using a contextual approach to interpret how constraints affect both teachers and students.

This study's findings also agree with Bennett et al.'s argument (1997) that the extent to which teachers are able to fulfil their ideal teaching orientations depends on various mediating factors (see Tables ' 1 ' \& ' 2 ' and the Qualitative results section). The findings also highlight the extremely powerful influence of external interpersonal constraints such as the expectations of the pupil's family, the school administration and inspectors, the nature of educational policy and its impact on the teachers' practices Cornbleth (2001) called these interpersonal constraints a 'conservative climate' which creates what he called 'socialization pressures' for the teachers. To avoid controversy and any negative consequences of any innovations, Administrators, teachers, and other school personnel tend to withdraw to presumably safer, traditional subject matter, materials, and activities. This situation puts pressure on teachers who try to follow new trend like STS.

The findings of the study also concur with Tsai (2002) who studied a science teacher's views of STS instruction. Tsai (2002) identified factors that may impede the success of STS instruction, including the syllabus outlined by national curriculum, standard tests, lack of administrative or peers' support, and resource limitations in the local contexts. Tsai also suggested that many aspects of existing political realties, situations, and cultures affect the implementation of STS.

One particular finding indicated that teachers' personal religious belief was among the most powerful personal factors that affected teachers' implementing of STS issues in the science classroom, their choices of teaching methods and also their style of interacting with students. They also highlighted the fact that teachers' lack of knowledge about Islamic-religious perspectives made them anxious and not confident enough to teach issues such as, for example, genetic engineering, or organ transfer or 
donation. This in turn influenced their practices in the classroom or their action plans for teaching these controversial issues. In this respect, these findings concurred with Mansour's (2007) personal religious beliefs (PRB) Model which argues that there are some factors that limit or facilitate the operation of teachers' plans or frameworks for action in the science classroom. Mansour (2007) also argues that transforming these frameworks of action into real practice in the science classroom depends on some social factors, e.g. constraints. Similarly, Reiss and Straughan (1996) argue that the moral beliefs that people hold about any subject, influence their perceptions of that subject and their attitudes towards it. Also, these beliefs will influence the way they see and interpret the world around them, which in turn shapes their choices and behaviours.

The findings of this study agree with those of Johnson, Monk and Swain (2000) and Gahin (2001) that there was interaction both within and between the external and internal constraints. For example, the lack of equipment was related to large class sizes which in turn influenced the time available for teaching/learning. Also the findings of the study indicated that constraints appear to be cyclical if not seasonal as well as multifaceted, nested and fluid. Also as Cornbleth (2001) notes, constraints, like the weather, are neither generic nor fixed. All of these constraints act to encourage teachers to conduct classes in less flexible way and display a firm stance toward the students. This results in a 'social distance' between teachers and their students (Bidwell, Frank and Quiroz, 1997). Over time, these constraints or the teacher's reactions/coping behaviours to the constraints may evolve into a set of beliefs, gradually cohering into a personal philosophy of teaching.

According to the Giddens's structuration theory, each of the various forms of constraints are also, in varying ways, forms of enablement. They serve to open up certain possibilities of action at the same time as they restrict or deny others (Giddens, 1984). Constraints enable traditional practices and restrict the constructivist practices. The findings of the study agreed with Giddens' conception of structure and agency i.e. that the range of free action which agents (teachers) have is restricted by external forces (e.g. the examination system, lack of time, work overload, high density in the classrooms, lack of STS resources or materials, the content, etc.) that set strict limits on what these teachers can achieve. For structuralists, human actions are largely 
determined by the social structures that people inhabit (Hodkinson, 2004). Similarly, Dirkx and Slusarski (2000) argue that the social structures in which teachers work profoundly shape their choices.

\section{Implications}

Many factors which act as barriers for teachers to put their beliefs into practice were identified and there was a mismatch between the teachers' expressed beliefs and their observed practices. Teachers' beliefs were mainly influenced by types of constraints which Ajzen $(1988,2002)$ called 'perceived behavioural control' or 'perceived control over the performance of behaviour' in his 'theory of planned behaviour'. The perceived behavioural control within the present study included external and internal constraints. To enable teachers to attempt to resolve inconsistencies between their beliefs and practices, relevant authorities, the Ministry of Education in Egypt in particular, should consider minimizing some of the constraining factors. Possible ways to do so include changing the emphasis of the Egyptian educational system from an examination-orientation (Hargreaves, 1997) to a learning-orientation, providing teachers with sufficient teacher education concerning STS, reducing curriculum content, supplying more appropriate resources and giving teachers more autonomy in their choice of teaching approach.

The findings of the study show that teachers' beliefs about the subject matter of STS issues influence teachers' decisions about what to teach, what to skip, and how much class time to devote to a particular issue. Therefore, before appropriate STS approaches can be implemented, teachers must have the opportunity to develop their views and beliefs about STS. When considering a STS approach to science education, teacher beliefs about STS implementation require attention from science educators during pre-service and in-service training. Without this attention, negative beliefs concerning STS implementation and constructivist learning could prevent implementation of teaching/learning science through STS. In addition, teachers must be involved in the actual development of the STS curriculum so they can build their knowledge concerning STS themes of teaching and learning and reform their beliefs in the process (Carroll, 1999). 
The findings of the study indicate how much pressure large class sizes put on teachers which in turn affects the quality of teaching and learning. The tendency of government and decision makers is to focus on cost considerations, influenced first and foremost by funding availability and local fiscal priorities, when making decisions regarding class size. In doing so, they may not sufficiently take into account considerations of education quality. To counter this, the teachers should be trained to be able to deal with large number of students and at the same time serious efforts should be made to reduce class sizes. Blatchford, et al. (2002) argues that initial teacher training and professional development is one way of maximizing potential advantages of smaller classes. Galton et al. (1996) also point out that currently there does not appear to be much preparation in initial teacher training concerning ways of adapting to class size. The Tennessee Student Teacher Achievement Ratio (STAR) project spawned a series of class size reduction initiatives in seven different states in the US, this project was summarized by Egelson et al. who concluded that;

\footnotetext{
"The outcomes of a reduced class size initiative included increased student achievement, a more focused instructional and assessment program in primary grades, with an emphasis on the individual learner, more time devoted to instruction and less on classroom discipline, better teacher-parent communication and improved student selfconcept and power relationships" (Egelson et al., 1995, p. 28).
}

The findings indicated that teachers perceive the principle sources of constraints as 'external constraints'. This raises the question of why Egyptian teachers feel this way. It is possible that they feel that most, if not all, of the decisions related to their career come from the outside in a 'top down' manner. They do not contribute to any decisions regarding curriculum development, teacher training, teacher preparation etc. so they do not feel that they have to take responsibility for any changes or innovations. Decision makers should consider teachers' views when they implement changes related to the educational system. Changing the status quo in the science curriculum cannot be achieved by STS-like curriculum improvements based on coherent philosophical grounds alone. Real change requires political interventions based on creative and power-brokering politics (Aikenhead, 2000).

This study showed how the setting or environment of classroom teaching and learning can influence what is taught - the context powerfully shapes STS teaching and thus 
affects students' opportunities to learn. The current study agreed with Cornbleth's (1990) argument that the focus of curriculum reform efforts ought to be on planning for desired curriculum practice. Therefore, attention ought to be paid to creating conditions supportive of STS curriculum practice as well as designing the practice itself. This involves creating conditions which recognize the constraints involved and finding ways of addressing them.

The findings showed up the effects of the school administration and the science supervisors on the inconsistency between teachers' beliefs and their practices. Kilgore and Ross (1990) suggest that providing considerable freedom to teachers to make instructional decisions helps them to match their beliefs and teaching practices. Also this study has highlighted the school administration as a powerful influence on teachers' beliefs and practices and the negative effect it has on implementing innovations like a STS curriculum. In this respect the study concurs with McNeil's (1986) conclusion that efforts to improve schooling (or teaching and learning) by means of regulations, accountability measures, or other controls -- what Cornbleth (2001) calls a "law and order" climate -- have the effect of encouraging traditional approaches to teaching and undermining meaningful learning and critical thinking that incorporates diverse perspectives and students. In addition, when the school's organization becomes centred on managing and controlling, teachers and students take school less seriously. They fall into a ritual of teaching and learning that tends toward minimal standards and minimum effort (e.g. 'teaching to the test'). This sets off a vicious cycle in which students disengage from enthusiastic involvement in the learning process and administrators often see the disengagement as a control problem. They then increase their attention to managing students and teachers rather than supporting their instructional purpose. This implies that the administrators should give teachers more support and more freedom to be able to create teaching environments conducive to the ideal of STS science teaching leading to scientific literacy and understanding of the social and technological implications of science.

The study also showed that teachers sometimes create a false contradiction between Islam and 'science and technology', which in turn, influences the teachers' feelings about choosing the teaching method to teach science through STS. For example, the teachers' comments indicated that they were confused about the Islamic views on 


\section{N. Mansour / Challenges to STS Education}

some STS issues e.g. genetic engineering. These teachers need to be educated as to the right relationship between religion and science. It is necessary to think about the compatibility between religious education and science education (Mansour, 2007).

Dadds (1995) and Lichtenstein, McLaughlin and Knudsen (1992) suggested that increased content knowledge went hand in hand with increased confidence, while having knowledge about teaching carried its own kind of authority that had the potential to empower teachers. This emphasized the significant role of teacher education in involving STS topics in the current teacher education program (Mansour, 2007).

The findings of the study also indicated a lack of professional knowledge that was a constraint for teachers in teaching STS issues. This could be overcome if in-service or pre-service teacher education offered courses in teaching STS that was designed for meeting the teachers' needs. There would seem to be a need for a survey examining teachers' needs and expectations from pre-service or in-service teacher programs. This would be useful for the educational institutions that are responsible for these professional development programs. Also, research should be conducted to identify appropriate content, context, structure and practices for teaching STS issues (Bybee \& Mau, 1986, Mansour, 2004).

\section{References}

Abell, S. K. (1990). A case for the elementary science specialist. School Science and Mathematics, 90 (4), 291-301.

Abell, S. K., \& Roth, M. (1992). Constraints to teaching elementary science: A case study of a science enthusiast student teacher. Science Education, 76 (6), 581-596.

Aikenhead, G. S. (2000). STS in Canada: From policy to student evaluation. In D.D. Kumar \& D.E. Chubin (Eds.), Science, technology, and society: A sourcebook on research and practice (pp.49-89). New York: Kluwer Academic/Plenum Publishers.

Ajzen, I (1988). Attitudes, personality, and behaviour. London: Open University Press, Milton Keynes.

Ajzen, I (2002). Perceived behavioural control, self-efficacy, locus of control, and the theory of planned behaviour, Journal of Applied social Psychology, 32, pp. 1-20.

Barnes, D. (1992). The significance of teachers' frames for teaching. In Russell, T. and Munby, H. (Eds.), Teachers and teaching: From classroom to reflection (pp. 9-32). London: the Farmer Press.

Bennett, N., Wood, L. \& Rogers, S. (1997). Teaching through play. Buckingham: open University Press. 
Bidwell, C., Frank, K. \& Quiroz, P. (1997). Teacher types, workplace controls, and the organization of schools. Sociology of Education, 70(4), pp.285-307.

Blase, J .J. (1986). A qualitative analysis of sources of teacher stress: Consequences for performance. American Education Research Journal, 23, 13-40.

Blatchford, P. Moriarty, V., Edmonds, S., \& Martin, C. (2002). Relationships between class size and teaching: A multimethod analysis of English infant schools, American Educational Research Journal, 39(1), 101-132.

Borg, M. G. (1990). Occupational stress in British educational settings: A review. Educational Psychology, 10, 103-126.

Borg, M. G., Riding, R. J., \& Falzon, J. M. (1991). Stress in teaching. A study occupational stress and its determinants, job satisfaction and career commitment among primary school teachers. Educational Psychology, 11, 59-75.

Brickhouse, N. W. (1989). the teaching of the philosophy of science in secondary classrooms: case studies of teachers' personal theories. International Journal of Science Education, 11, 437-449.

Bybee, R., \& Mau, T. (1986). Science and technology related global problems: in international survey of science educators. Journal of Research in Science Education, 23 (7), 599-618.

Carroll, T. M. (1999). Developing partnerships: teacher beliefs and practices and the STS classroom. Proceedings of the 1999 Annual international conference of the association for the Education Teachers in Science (pp.331-338). Greenville, NC: Association for the Education of Teachers in Science. (ERIC Document Reproduction Service No. ED 431626)

Clark, C. M., \& Peterson, P. L. (1986). Teachers' thought processes. In M. C. Wittrock (Ed.) Handbook on research in teaching (pp. 255-296). New York: Macmillan Publishing Co.

Cornbleth, C. (1990). Curriculum in context. London: Falmer Press.

Cornbleth, C. (1991). Research on context, research in context. In J. P. Shaver (Ed.) Handbook of research on social studies teaching and learning, pp. 265-275. New York: Macmillan.

Cornbleth, C. (2001). Climates of constraint/restraint of teachers and teaching. In W. B. Stanley (Ed.), Critical issues in social studies research for the 21 st century. Greenwich, CT: Information Age Publishing.

Dadds, M. (1995). Passionate Enquiry and School Development: A story about teacher action research. London: Falmer Press.

Denzin, N \& Lincoln, Y. (2000). Handbook of Qualitative Research, 2nd ed. London: SAGE.

Dirkx, J., Kushner, J. \& Slusarski, S. (2000). Are we walking the talk? Questions of structure and agency in the research on teaching in adult education. A paper presented on An International Conference "The Right Quest/ions: Research/ ing in a New Century" The 41st Annual, Adult Education Research Conference June 2-4.

Egelson, P., Harman, P., \& Achilles, C. M. (1995). Does class size make a difference? Recent findings from state and district initiatives. University of North Carolina at Greensboro: SERVE (South Eastern Regional Vision for Education).

Ernest, P. (1988). The Impact of Beliefs on the Teaching of Mathematics. Paper was presented as at 6th International Congress of Mathematical Education, Budapest, August.

Ertmer, P.A., Addison, P., Lane, M., Ross, E., \& Woods, D. (1999). Examining teachers' beliefs about the role of technology in the elementary classroom. Journal of Research on Computing in Education, 32(1) 54-72.

Gahin, G. H. (2001). An investigation into EFL teachers' beliefs and practices in Egypt An explanatory study, Ph.D Thesis, school of Education, University of Exeter. 
Galton, M. Hargreaves, L. \& Pell, A (1996). Class size, teaching, and pupil achievement. Report for National Union of Teachers, Leicester University.

Giddens, A. (1984). The constitution of society: Outline of the Theory of Structuration. Berkeley, University of California Press.

Hamilton, M., \& Richardson, V. (1995). Effects of the culture in two schools on the process and outcomes of staff development. Elementary School Journal, 95(4), 367-385.

Hargreaves, E. (1997). The diploma disease in Egypt: Learning, teaching, and the monster of the secondary leaving certificate. Assessment in Education: principles, Policy \& Practice, 4(1) 161-176.

Hodkinson, P. (2004). Theoretical constructions of workplace learning: Troubling dualisms and problems of scale. A paper presented on European Society for Research on the Education of Adults (ESREA) Research Network Working Life and Learning, at Northern College, 12 - 14 November.

Johnson, S. Monk, M. \& Swain, J. (2000). Constraints on development and change to science teachers' practice in Egyptian classrooms. Journal of Education for Teaching, 26(1), 9-24.

Kagan, D. (1992). Implications of research on teacher belief. Educational Psychologist, 27(1), 65-90.

Kelly A. L., \& Berthelsen, D. C. (1995). preschool teachers' experiences of stress, Teaching \& Teacher Education, 11 (4), 345-357.

Kilgore, K., Ross, D., \& Zbikowski, J. (1990). Understanding the teaching perspectives of first-year teachers. Journal of Teacher Education, 41(1), 28-38.

Lichtenstein, G., M. W. McLaughlin. \& J. Knudsen (1992). Teacher empowerment and Professional knowledge. in A. Lieberman (eds.), The Changing Contexts of Teaching. Chicago: The University of Chicago Press, pp. 37-58.

Mansour, N. (2004). Does the Egyptian preparatory science curriculum provide for the development of the Scientific Literacy (SL)? Paper at the Annual Staff Student Research Conference at the School of Education and Lifelong Learning, University of Exeter, 15 May, Exeter, UK.

Mansour, N. (2006). The mediating factors between Egyptian science teachers' beliefs and practices concerning teaching science through Science-Technology-Society (STS): Implication for science education. Paper presented at the annual conference of the British Educational Research Association (BERA) University of Warwick, UK, 9-6 September.

Mansour, N. (2007). The experiences and personal religious beliefs of Egyptian science teachers as a framework for understanding the shaping and reshaping of their beliefs and practices about Science-Technology-Society (STS). International Journal of Science Education. (in press)

Maxion, S. P. (1996). The influence of teachers' beliefs on literacy development for at-risk first grade students. Paper presented at the annual meeting of the American association of colleges for teacher education (48th, Chicago, IL, February 21-24. (ERIC Document Reproduction service No. ED 392780).

McNeil, L.M. (1986). Contradictions of control: School structure and school knowledge. New York \& London: Routledge \& Kegan Paul.

Miles, M. B. \& Huberman, A.M. (1994). Qualitative data analysis. Thousand Oaks, CA: Sage.

Olson, J. K. (1988). School world/micro-worlds: Computers and culture of the school. England: Pergamon.

Otto, R. (1986). Teachers under stress: health hazards in work role and modes of response. Melbourne: Hill of Content. 
Pajares, M. F. (1992). Teachers' beliefs and education research: Cleaning up a messy construct. Review of Education Research, 62, 307-332.

Pedersen, J. E., \& Totten, S. (2001). Beliefs of science teachers toward the teaching of science/technology/social issues: Are we addressing National Standards? Bulletin of Science, Technology \& Society. 21 (5), 376-393.

Pedretti, E., \& Hodson, D. (1995). From rhetoric to action: Implementing STS education through action research. Journal of Research in Science Teaching, 32, 463-485.

Reiss, M. J. \& Straughan, R. (1996). Improving Nature? the Science and Ethics of Genetic Engineering. London: Cambridge University Press.

Simonneaux, L. \& Albe, V. (2002). Teaching socially controversial scientific: resistances and motivations, real or perceived ? In J. Lewis, A. Magro, L. Simonneaux (Eds.),Biology Education For The Real World -Student - Teacher - Citizen (121-134). Toulouse : ERIDOB - ENFA.

Tsai, C. (2002). Nested epistemologies: science teachers' beliefs of teaching, learning and science. International Journal of Science Education, 24(8), 771-783.

United Nations Educational, Scientific, and Cultural Organization (UNESCO): Education For All 2000 Assessment: Country Reports, Egypt. Reviewed 02 February 2004. Available at: http://www2.unesco.org/wef/countryreports/egypt/rapport_1_1.htm ().

Zeichner, K.M., Tabachnick, B.R., \& Densmore, K. (1987). Individual, institutional, and cultural influences on the development of teachers' craft knowledge. In J. Calderhead (Ed.), Exploring teachers' thinking (pp. 21-59). London: Cassel.

\section{Biographical Note}

Nasser Mansour is a Lecturer in Science Education at the Faculty of Education, Tanta University, Egypt. He did work as a research assistant on a research project to assess the "Continuing Professional Development" (CPD) programme, at School of Education and Lifelong Learning, University of Exeter, United Kingdom.

He holds BSc (grade Very Good/Honours) in Physics \& Chemistry Education, and an MA in Science Education (grade Excellent) from the Faculty of Education, Tanta University, Egypt. His $\mathrm{PhD}$ in Science Education is from the School of Education and Lifelong Learning, University of Exeter. He also holds a Diploma in Understanding Children from the Open University, United Kingdom.

He originated the "Personal Religious Beliefs (PRB) Model", which explains the process of shaping and reshaping teachers' beliefs and practices. He is a reviewer for the British Educational Research Association (BERA) conference. He is a member of several educational associations; BERA (British Educational Research Association, UK); ESERA (European Science Educational Research Association, Netherlands); BAAS (British Association for the Advancement of Science, UK); and NARST (National Association for Research in Science Teaching, USA).

His main research interests are in aspects of teaching and learning in science, including STS (Science, Technology and Society education); controversial issues, scientific literacy, the relationship between religion and science education; learners' ideas, misconceptions, alternative conceptions and alternative frameworks; constructivism in science education; learner thinking; creative thinking in science explanations in science; teaching about the nature of science; science teachers' beliefs and practices, teacher professional development; and Grounded Theory. 